\title{
A social work study on violence against women
}

\author{
Mohammad Reza Iravani $^{a^{*}}$, Najmeh Sedrpoushan ${ }^{\mathrm{b}}$ and Imaneh Afghami Ardakani ${ }^{\mathrm{c}}$
}

${ }^{a}$ Department of Social Work, Islamic Azad University of Khomeinishahr, Khomeinishahr Branch, Daneshjou Blvd, Iran
${ }^{b}$ Counselling Department, Islamic Azad University of Khomeinishahr, Khomeinishahr Branch, Daneshjou Blvd, Iran

${ }^{b}$ Counselling Department, Islamic Azad University of Khomeinisha
${ }^{c}$ Islamic Azad University, Science \& Research Branch, Yazd, Iran

$\begin{array}{ll}\text { A R T I C L E I N F O A S T R A C T } & \text { A }\end{array}$

Article history:

Received July 10, 2011

Received in Revised form

October, 3, 2011

Accepted 10 January 2012

Available online

15 January 2012

Keywords:

Violence against women

Esfahan

Family dispute
Violence against women has been one of the most controversial issues in modern societies. During the past few decades, there have been tremendous efforts on providing supports for women against any kind of family violence and dispute. The proposed study of this paper attempts to investigate women's position on domestic violence. We design a questionnaire and distribute among 880 people who are randomly chosen from a population of 441782 residences who live in city of Esfahan, Iran. The result of our survey confirms that Iranian women experienced different types of violence in their lives. The study also suggests some guidelines based on an adaptation of advices in other countries in an attempt to reduce the rates of crime, significantly.

\section{Introduction}

Violence against women has been one of most controversial issues for thousands of years. There have been many attempts on behalf of many organizations to reduce the rate of violence against women. There are many factors such as cultural, economical, social issues, which are blamed for having such incidents. For instance, in one region of a country, we can see more violence than other regions due to existence of some sort of traditions. Female mutilation, for instance, is one of the sever traditions against women in some regions of the world especially in African countries. Every year, several young girls are brutally injured and some of them die because of this action. The convention on the elimination of all forms of discrimination against women (CEDAW) is one of the most important efforts on defending women's right in the world. Cook (1997) investigated the relative importance of cooperating with human rights convents to progress health and self-determination in the work.

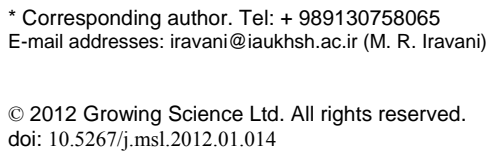


CEDAW was adopted in 1979 by United Nations General Assembly and it is stated as an international bill of rights for women. The concept of the convention is to create a basis for realizing equality between women and men through guaranteeing women's equal achievement and equal opportunities in public life. It incorporates the right to vote in all elections, education, health and employment.

During the past few decades, there have been various studies on CEDAW rules and regulations (Moghadam, 1991). Gray (1998) discussed this issue through gathering ideas from experts from a narrative using interviews with educated Sudanese women. Gray provided some guidelines for removing this option of actions as a legal rule in CEDAW. Domestic violence is the other important discrimination against women in the world.

Ergö nen et al. (2009) addressed domestic violence on pregnant women in Turkey and discussed that since the country signed the CEDAW commitment, it should take the necessary attempts for stopping such movements. They studied the prevalence of domestic violence during pregnancy among the women who visited some clinics and provided some legal recommendation concerning domestic violence.

Reilly (2007) discussed that global-level feminist advocacy in the 90s had had a significant impact within feminist advocacy in Republic of Ireland. She determined six approaches to women's human rights advocacy in Ireland including human rights facilitating collective action, local-global transformation, human rights as modes of legal accountability, human rights for social and economical activities. She argued that these advances could reflect a new, outwardly oriented departure in the Irish women community.

Bryant and Raphael (2004) studied the welfare state as a way of women's health and a support for women's quality of life in Canada. In a practical study, they collected some necessary information associated with quality of life of women in Canada and compared their information with those women who live in four other countries of Denmark, Sweden, the UK and the US. They presented a consistent results in all countries based on social welfare benefits.

Romero and Agénor (2009) studied the impact of the US welfare reform family-cap policy on the childbearing decisions of low income and poor women. They argued that the policy could not have a good impact on poor women's reproductive health behavior and recommended to re-engineer the rules and regulations.

Hilsdon (2006) performed a detailed investigation on the case of human right and migration for a case study of Filipino Muslim women in Malaysia. In this country, several refugees fled Mindanao after some conflict on Muslim groups escalated in that region. However, the migration of the workers to Malaysia impacted the labor market and there was a conflict among local residence and immigrants. Migrant Muslim women experienced tremendous violence on a number of issues such as oppression at the level of citizenship, institutions and culture, economic, etc.

Hilsdon (2006) investigated the issues through life narratives, the parameters of such violence and women's resistance, providing some guidelines for improving rules and regulations. 
The present study of this paper investigates violence among women who live in one the biggest provinces of Iran, Esfahan. The proposed study of this paper first presents details of our survey in section 2 and section 3 provides the results of our investigation. Finally, concluding remarks are given in the last to summarize the contribution of this paper.

\section{The proposed study}

According to the official census held in 2006, there are 5026 people residing in this city including 2575 men and 2451 women. We have used the following formula to calculate the minimum number of sample size,

$$
n=\frac{N \times z_{\alpha / 2}^{2} \times p \times q}{\varepsilon^{2} \times(N-1)+z_{\alpha / 2}^{2} \times p \times q},
$$

where $N$ is the population size, $p=1-q$ represents the yes/no categories, $z_{\alpha / 2}$ is CDF of normal distribution and finally $\varepsilon$ is the error term. Since we have $p=0.5, z_{\alpha / 2}=1.96, \varepsilon=0.033$ and $N=441782$, the number of sample size is calculated as $n=880$. Table 1 shows educational backgrounds of the participants.

\section{Table 1}

Distribution of the sample by educational level

\begin{tabular}{lcc}
\hline Educational level & Frequency & Percent \\
\hline Illiterate & 196 & 22.3 \\
Primary & 131 & 14.8 \\
Middle & 37 & 4.2 \\
Secondary & 313 & 35.6 \\
Graduate & 81 & 9.2 \\
Post-graduate & 96 & 10.9 \\
Ph D & 26 & 3.0 \\
\hline Total & 880 & 100.0 \\
\hline Chi-square $=483.15 ; \mathrm{P}=.000$ & &
\end{tabular}

Education-wise, most of the sample belonged to secondary level of education $(35.6 \%)$, which is followed by illiterates $(22.3 \%)$. A glimpse at the table clearly reveals that we find less and less number of Iranian female respondents having higher levels of education. From graduation to Ph.D we find on the whole only about $3 \%$. Further, chi-square test revealed significant difference between different frequencies of educational levels. Table 2 demonstrates the nature of employment among people who tool part in our survey.

Table 2

Distribution of the sample by present occupation

\begin{tabular}{lll}
\hline Occupation & Frequency & Percent \\
\hline Business/industrialist & 10 & 1.1 \\
Salaried employment & 31 & 3.6 \\
Temporary govt job & 10 & 1.1 \\
Regular private sector job & 12 & 1.4 \\
Temporary private sector job & 8 & 0.9 \\
Petty trader shop keper & 7 & 0.8 \\
Self employed professional & 7 & 0.8 \\
Other & 3 & 0.3 \\
Not Applicable & 792 & 90.0 \\
\hline Total & 880 & 100.0 \\
\hline Chi-square $=5550.29 ; \mathrm{P}=.000$ & &
\end{tabular}


It was quite alarming fact that $90 \%$ of the Iranian women sample selected did not have any job. $3.6 \%$ of them were on salaried employment, $1.4 \%$ of them were on regular private sector job, very few of them were in business/industrialists, few of them had temporary government jobs as well as temporary private jobs. One of the question these peope were asked was on the existence of violence among them. We asked them whether they recall any time conflicts had taken place in their family. Table 3 shows details of our survey on this question.

\section{Table 3}

The experience of violence among survey people

\begin{tabular}{lccc}
\hline Sl no & Response & Frequency & Percent \\
\hline 1 & No & 244 & 27.7 \\
2 & Yes & 636 & 72.3 \\
\hline & Total & 880 & 100.0 \\
\hline
\end{tabular}

Chi-square $=91.87 ; \mathrm{P}=.000$

$72.3 \%$ of the sample reported that they could recall conflicts, which had taken place, and remaining $27.7 \%$ of them indicated 'no'. When chi-square test was applied, a significant difference was observed between frequencies of responses. Table 4 shows details of the violence they experience.

\section{Table 4}

Type of violence survey people experienced

\begin{tabular}{llll}
\hline Sl no & Response & Frequency & Percent \\
\hline 1 & Physical abuse & 187 & 21.3 \\
2 & Verbal abuse & 262 & 29.8 \\
3 & Not talking to each other & 122 & 13.9 \\
4 & others & 65 & 7.4 \\
5 & Not applicable & 244 & 27.6 \\
\hline & & 880 & 100.0 \\
\hline
\end{tabular}

Chi-square $=89.14 ; \mathrm{P}=.000$

When they were asked further, $21.3 \%$ indicated physical abuse, $29.8 \%$ indicated verbal abuse, $13.9 \%$ indicated not talking to each other, and $7.4 \%$ indicated other type of conflicts. When chi-square test was applied, a significant difference was observed between frequencies of responses.

\section{Table 5}

Frequency of the conflicts led to physical violence along with chi-square test

\begin{tabular}{llll}
\hline Sl no & Response & Frequency & Percent \\
\hline 1 & Yes & 476 & 54.1 \\
2 & No & 160 & 18.3 \\
3 & Not applicable & 244 & 27.6 \\
\hline & Total & 880 & 100.0 \\
\hline
\end{tabular}

Chi-square=357.53; $\mathrm{P}=.000$

$54.1 \%$ of the sample indicated that they were beaten or mistreated physically, $18.3 \%$ indicated 'no' and remaining $27.6 \%$ of the responses were not applicable. When chi-square test was applied, a significant difference was observed between frequencies of responses.

\section{Table 6}

Frequency and percent response for the person who beat physically and results of chi-square test

\begin{tabular}{llcc}
\hline S1 no & Response & Frequency & Percent \\
\hline 1 & Parents & 41 & 4.7 \\
2 & Brother & 61 & 6.9 \\
3 & Sister & 8 & 0.9 \\
4 & Husband & 433 & 49.2 \\
5 & In laws & 50 & 5.8 \\
6 & Others & 43 & 4.9 \\
7 & No such things & 244 & 27.6 \\
\hline
\end{tabular}


Most of the respondents (49.2\%) indicated that their husband had beaten them or mistreated physically, $6.9 \%$ brother, $4.9 \%$ others, $4.7 \%$ by parents. $27.6 \%$ of them indicated no such things. When chi-square test was used, a significant difference existed between frequencies of responses.

Table 7

Association between educational level and domestic violence among Iranian women

\begin{tabular}{|c|c|c|c|}
\hline \multirow{2}{*}{ Educational level } & \multicolumn{2}{|r|}{ Domestic violence } & \multirow[b]{2}{*}{ Yes } \\
\hline & & No & \\
\hline \multirow[t]{2}{*}{ Illiterate } & Frequency & 7 & 189 \\
\hline & Percent & $3.6 \%$ & $96.4 \%$ \\
\hline \multirow[t]{2}{*}{ Primary } & Frequency & 2 & 129 \\
\hline & Percent & $1.5 \%$ & $98.5 \%$ \\
\hline \multirow[t]{2}{*}{ Middle } & Frequency & 6 & 31 \\
\hline & Percent & $16.2 \%$ & $83.8 \%$ \\
\hline \multirow[t]{2}{*}{ secondary } & Frequency & 155 & 158 \\
\hline & Percent & $49.5 \%$ & $50.5 \%$ \\
\hline \multirow[t]{2}{*}{ Graduate } & Frequency & 8 & 73 \\
\hline & Percent & $9.9 \%$ & $90.1 \%$ \\
\hline \multirow[t]{2}{*}{ Postgraduate } & Frequency & 33 & 63 \\
\hline & Percent & $34.4 \%$ & $65.6 \%$ \\
\hline \multirow[t]{2}{*}{$\mathrm{Ph} \mathrm{D}$} & Frequency & 22 & 4 \\
\hline & Percent & $84.6 \%$ & $15.4 \%$ \\
\hline \multirow[t]{2}{*}{ Total } & Frequency & 233 & 647 \\
\hline & Percent & $26.5 \%$ & $73.5 \%$ \\
\hline Contingency coefficient & & .464 & \\
\hline P value & & .000 & \\
\hline
\end{tabular}

In the case of domestic violence again occupational level had significant influence, where contingency coefficient of .464 was found to be significant at .000 level. It is clear that those with lower levels of education experienced more of domestic violence compared to those with higher levels of education.

\section{Table 8}

Association between occupational level and domestic violence among Iranian women

\begin{tabular}{llll}
\hline Occupation & & No & Yes \\
\hline Business/ Industrialist & $\mathrm{F}$ & 2 & 8 \\
& $\%$ & $20.0 \%$ & $80.0 \%$ \\
\hline Salaried employment & $\mathrm{F}$ & 4 & 27 \\
& $\%$ & $14.8 \%$ & $85.2 \%$ \\
\hline Temporary govt job & $\mathrm{F}$ & 2 & 8 \\
& $\%$ & $20.0 \%$ & $80.0 \%$ \\
\hline Regular private sector job & $\mathrm{F}$ & 4 & 8 \\
& $\%$ & $33.3 \%$ & $66.7 \%$ \\
\hline Temporary private sector job & $\mathrm{F}$ & 1 & 7 \\
& $\%$ & $12.5 \%$ & $87.5 \%$ \\
\hline Petty trader shop keeper & $\mathrm{F}$ & 0 & 7 \\
& $\%$ & $0 \%$ & $100.0 \%$ \\
\hline Self employed professional & $\mathrm{F}$ & 1 & 6 \\
& $\%$ & $16.7 \%$ & $83.3 \%$ \\
\hline Other & $\mathrm{F}$ & 0 & 3 \\
& $\%$ & $0 \%$ & $100.0 \%$ \\
\hline Total & $\mathrm{F}$ & 14 & 64 \\
& $\%$ & 21.7 & 72.3 \\
\hline Chi-square & & 5.158 & \\
\hline P value & & .621 & \\
\hline
\end{tabular}


In the case of domestic violence again occupational level had a non-significant influence, where chisquare value of 5.158 was found to be non significant. On the whole, we found $72.3 \%$ of them experienced domestic violence, where such incidents were similar for all types of occupations statistically.

\section{Results and discussion}

Based on the results we gathered earlier we can summarize the following,

a. An alarming $72.3 \%$ of the women reported domestic violence, and most of them were in the form of verbal and physical abuse and least of not talking to each other.

b. Many of them opined that they could recall those conflicts that led to violence. Husband was the major source of violence.

c. Those who had lower levels of education, had experienced more domestic violence than respondents with higher levels of education. Occupation as such did not have any significant influence over domestic violence.

\subsection{Hypothesis: Rate of domestic violence is quite high in Iran in various forms}

The hypothesis is accepted as we find in the respondents' opinion that $54 \%$ of the women reported domestic violence, and most of them were in the form of verbal and physical abuse and least of not talking to each other.

Unfortunately, the fanatical extremism has continued to resist any change that reflects social reality. The moderate ruling faction and its policy of moderation have resulted, on the whole, in the passage of certain laws relating to the status of women. To some extent, they have improved the situation. In particular, within the last several years, government tried to pass laws and rules to reduce the harshness of laws against women. However, their efforts have never crossed the lines beyond which they could be exposed to attacks by the conservatives, who easily resort to allegations of promoting the onslaught of the Western culture as a weapon of war. The moderates have never been able, or willing, to overcome the attitude of extremist traditionalists who base their arguments on ancient interpretations of religious texts. The limit of reforms intended by the moderates has been certain changes to improve the legal rights of women.

It is clear to see that the hardships and obstacles women face in Iran are the results of conservative teachings, a burning desire to live Allah's will, and a revolution that will never be forgotten. However, one must question whether this was totally Allah's plan. In regard to some of the quotes from the Quran, if men have a "degree" over women, how could Allah have possibly declared them equal? In addition, if the two genders are equal, how could a follower of Islam possibly place discriminatory laws against women to the great effect that they are? It is necessary to question if the extent to which women are discriminated against truly is necessary. The boundaries that should be in place in every society have been crossed entirely too far.

\subsection{Violence prevention strategies for women}

Domestic violence occurs with a high prevalence rate in different societies around the world. The types and risk factors of domestic violence seem to be similar throughout the world irrespective of differences in cultural and religious backgrounds.

Early detection and intervention programs should be established in public health services. As we mentioned in upper parts, domestic violence can have lasting consequences on the victims' life. It also adversely affects the psychological development of the children. Domestic violence can also tragically result in the murder of the victim. It is important thus, to tackle this problem by increasing 
the awareness of the victims and supporting them to report any form of abuse as early as possible to pave the way for establishing a safe and healthy family life. The survival of emerging women's support services will be vital to the welfare of women and families.

- Women's committee can improve quality and quantity and government can help make more active, so it will be able to control violence against women.

- Women's committee whether governmental or in government can support violence victimize by consulting services and defending services, so they should prepare facilities for any committer rather than other agent organizations.

Recently, rate of violence has escalated in Iranian society, so police officers are not as sensitive as ordinary people are. Even sometimes, they try not to interface in family's issue. They think that sometimes violence is natural and necessary and when compliance women phone to the police, they will not pay attention to it, because they think that it is very less important. Without being activity for women's committee in any part and make relationship between them and police, we cannot be able to help victimizes.

\section{Conclusion}

In this paper, we have presented a comprehensive survey to investigate violence against women who live in a city of Esfahan, Iran. We have designed a questionnaire and distributed among 880 people who were randomly chosen from a population of 441782 residence. The results of our survey confirmed that Iranian women experienced different types of violence in their lives. The study also suggested some guidelines based on an adaptation of advices in other countries in an attempt to reduce the rates of crime, significantly. We have conluded that govermental agencies cannot solely fight against this issue since there other important crimes in the country and they have prioritized their activities based on the relative importance. Therefore, community must take more care about what is going on in the country and people's lives and we must provide more awareness in society to fight against any kind of violences.

\section{Acknowledgment}

The author would like to thank Islamic Azad University for their financial support on this project. The author also grateful for constructive comments received from the anonymous referees on earlier version of this working paper.

\section{References}

Bryant, T., \& Raphael, D. (2004). The welfare state as a determinant of women's health: support for women's quality of life in Canada and four comparison nations. Health Policy, 68(1), 63-79.

Cook, R. J. (1997). UN human rights committees advance reproductive rights. Reproductive Health Matters, 5(10), 151-153.

Erg nen, A.T., Özdemir, M. H., Can, I.Ö, \& S nmez, E., Sala in, S., Berbero lu, E., \& Demir, N. (2009). Domestic violence on pregnant women in Turkey. Journal of Forensic and Legal Medicine, 16(3), 125-129.

Gray, C. S. (1998). A case history based assessment of female genital mutilation in Sudan. Evaluation and Program Planning, 21(4), 429-436.

Hilsdon, A.-M. (2006). Migration and human rights: The case of Filipino Muslim women in Sabah, Malaysia. Women's Studies International Forum, 29(4), 405-416.

Lloyd, C. (2006). From taboo to transnational political issue: Violence against women in Algeria. Women's Studies International Forum, 29(5), 453-462.

Moghadam, V. M. (1991). The reproduction of gender inequality in Muslim societies: A case study of Iran in the 1980s. World Development, 19(10), 1335-1349. 
1416

Reilly, N. (2007). Linking local and global feminist advocacy: Framing women's rights as human rights in the Republic of Ireland. Women's Studies International Forum, 30(2), 114-133.

Romero, D., \& Agénor, M. (2009). US fertility prevention as poverty prevention: An empirical question and social justice issue. Women's Health Issues, 19(6), 355-364.

Zampas, C., \& Lamaćková, A. (2011). Forced and coerced sterilization of women in Europe. International Journal of Gynecology \& Obstetrics, 114(2), 163-166. 